\title{
WATER RESOURCES IN THE WIDER AREA OF THE APOSELEMIS BASIN, CRETE ISLAND, GREECE
}

\author{
Voudouris K. ${ }^{1}$, Alexopoulos A. ${ }^{2}$, Antonakos A. ${ }^{3}$, and Kallergis G. ${ }^{4}$ \\ ${ }^{1}$ Lecturer, Lab of Engineering Geology \& Hydrogeology, Dept. of Geology, Aristotle Universit \\ y, GR 54124,Thessaloniki, Greece.E-mail: kvoudour@geo.auth.gr \\ ${ }^{2}$ Associate Prof., Faculty of Geology \& Geoenvironment, National \& Kapodistrian Univ. of \\ Athens \\ ${ }^{3}$ Geologist, MSc of Environmental Geology \\ ${ }^{4}$ Emeritus Prof. of Hydrogeology, University of Patras
}

\begin{abstract}
The estimation of hydrologic balance is useful in order to assess the safe yield of the aquifer systems and therefore to establish their rational exploitation and sustainable management. Over-abstractions of groundwater in Aposelemis basin resulted in a severe disequilibrium of its water balance. In order to overcome this disequilibrium we studied the hydrological balance in the wider area of Dikti mountain which comprises the drainage basins of Aposelemis river, of Lasithi and Katharo plateaus and of the rest of the drainage area of Dikti. The data used are the monthly values of Aposelemis runoff in the gauge station at Potamies and rainfall data for the period 1967-2003 from seven stations located within or in the close vicinity of the drainage basin of Aposelemis. Using ArcView GIS, the hydrological basin of Aposelemis river and the drainage area of Dikti were delineated, based on the digital elevation model (DEM). The actual evapotranspiration was estimated by the Thornthwaite method. A high inter-relationship exists between the flow of the Aposelemis river and rainfall outside the conventional boundaries of the Aposelemis basin. A significant portion of the annual rainfall, in that wider area is not only recharging the karst systems downstream but also contributing to the flow of Aposelemis river. Karst aquifer systems are partially drained by large coastal and submarine brackish springs and by inland freshwater springs. Finally, tracer studies carried out by IGME confirmed the hydraulic connection between Lasithi plateau and downstream aquifer systems.
\end{abstract} Key words: Hydrologic balance, karst aquifer, Aposelemis, Dikti mountain, Crete.

\section{Пврі́іпчи}

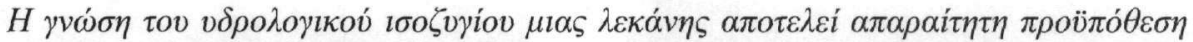

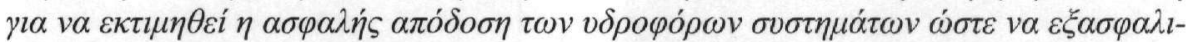

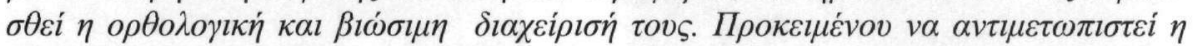

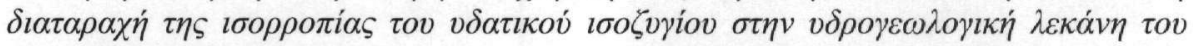

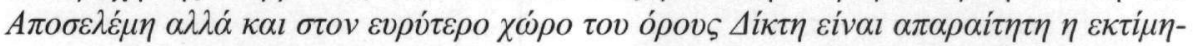

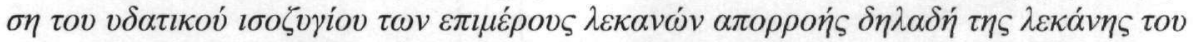

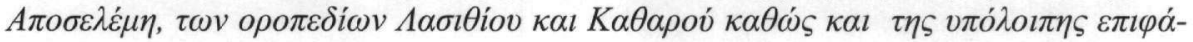




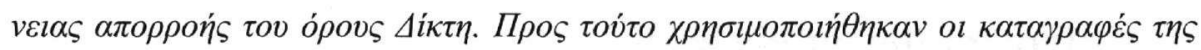

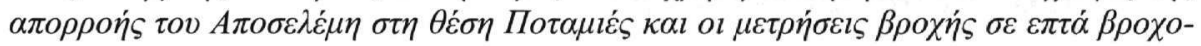

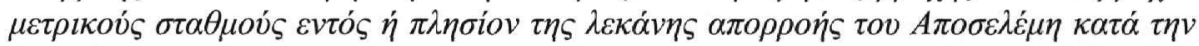

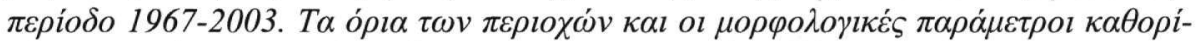

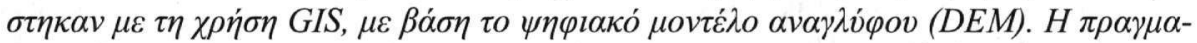

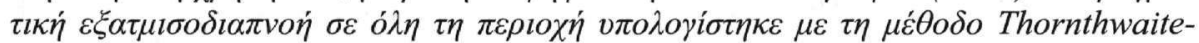

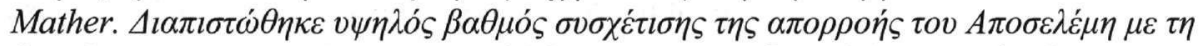

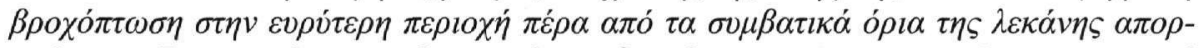

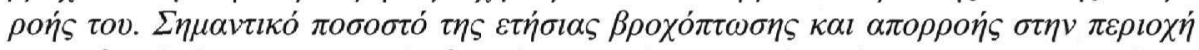

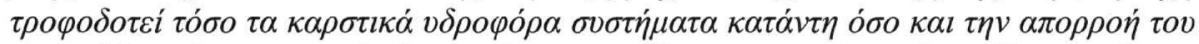

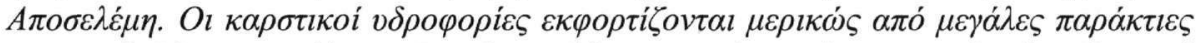

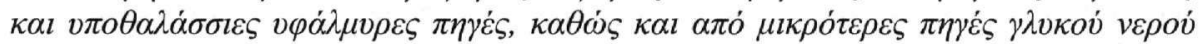

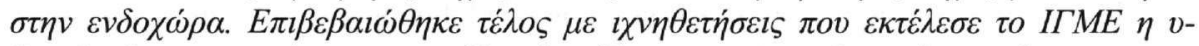

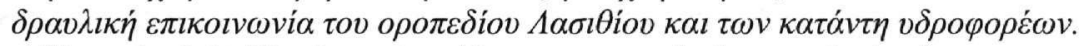

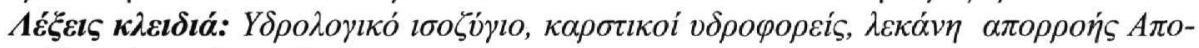

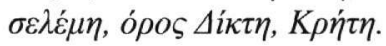

\section{Introduction}

The availability of water resources is the most decisive controlling factor for the economic and social development of island of Crete. The water demands are predominantly met by the exploitation of aquifers, through a large number of water wells. The most important limiting factor for any sustainable water resources management scheme is the regional and seasonal variation in water availability and demand. About $70-80 \%$ of annual precipitation occurs in 3-4 months, while summers are usually long and dry. Furthermore, both agriculture and tourism require increased supplies in late spring, summer, and early autumn, when water is less abundant (Chartzoulakis et al. 2001).

Depletion and pollution of coastal aquifers from sea water intrusion occurred during the last decades due to the over-pumping of aquifers, especially during long-lasting dry periods. As a consequent high drawdown of ground water level resulted due to imbalance between recharge and abstractions from the aquifer systems. Water levels at depths of several meters below m.s.l. were recorded. The overexploitation of coastal aquifers has gradually led to a significant deterioration in groundwater quality. The adverse effects are depicted by the high concentrations of chlorides, due to seawater intrusion (Lambrakis 1998, Kallergis et al. 2000, Voudouris et al. 2004). To assess the possibility of reversing this situation it is necessary to define the components of water budget in the basin. The knowledge of those components may contribute to the optimisation of water resources management and to overcome the disequilibrium in the water balance of the basin.

The present paper deals with the estimation of the hydrologic budget in Aposelemis basin. Given that the Aposelemis basin receives both runoff and groundwater from outside its conventional boundaries the research was extended to Lasithi and Katharo plateaus and to the rest of the drainage area of Dikti mountain. All existing geological, hydrological, hydrogeological, and hydrochemical data were evaluated and reworked. Using ArcView GIS, the hydrological basin of Aposelemis river and the drainage area of Dikti were delineated and their morphological features (mean slope, range of elevation, mean elevation etc) were calculated, based on the digital elevation model (DEM). This scientific work was carried out by the Aristotle University of Thessaloniki, in the framework of a research project funded by Municipality of Chersonisos. 


\section{Morphology of the study area}

\subsection{Aposelemis basin}

The basin of the Aposelemis river is located in the north-central part of the island of Crete (Fig. 1), covering an area of $122.7 \mathrm{~km}^{2}$. The maximum elevation is $1541 \mathrm{~m}$, the mean $441 \mathrm{~m}$ and the mean slope is $15.5 \%$ (Table 1). The total length of the river Aposelemis is $23 \mathrm{~km}$ and discharges into the Cretan sea.

\subsection{Lasithi plateau}

The Lasithi plateau, including the Katharo plateau, covers an area of $129.2 \mathrm{~km}^{2}$. The low-land area of the plateau $\left(45 \mathrm{~km}^{2}\right)$ is covered by alluvial deposits $10 \mathrm{~m}$ thick. The mean slope is $12.7 \%$. It is drained by the torrent Chavga, ending in the sinkholes of Chonos and Vidiani, at elevation $800 \mathrm{~m}$ a.s.1. An amount of water, which infiltrates in the Chonos sinkole, discharges through the springs of Ag. Georgios (Kastamonitsa) and recharges the streamflow of the Aposelemis river. The maximum surface drainage capacity of the Chonos sinkhole is $10-12 \mathrm{~m}^{3} / \mathrm{s}$.

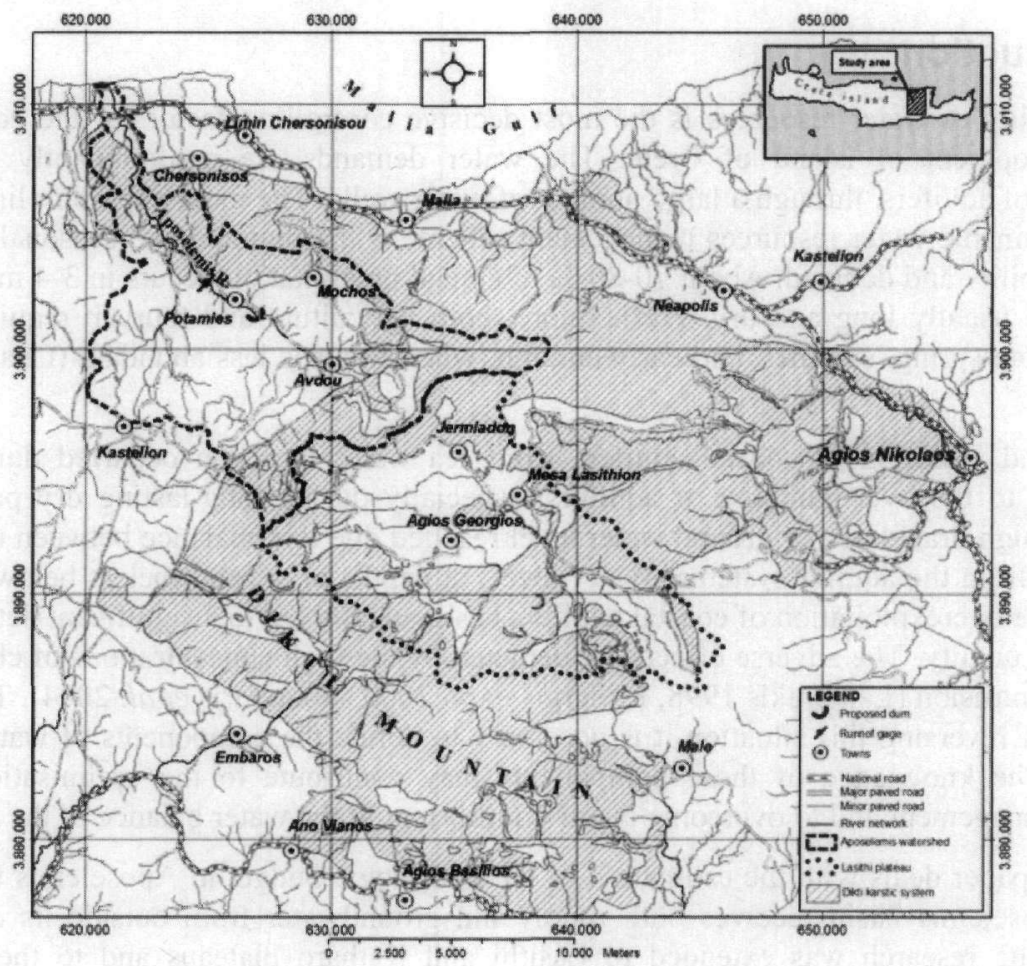

Figure 1 - Location of the study area

\subsection{Dikti mountain}

The carbonate mass of the Dikti mountain is one of the most important karstic hydrogeological systems in the island of Crete. It covers an area of $451.5 \mathrm{~km}^{2}$. The mean altitude is $878 \mathrm{~m}$ and the mean slope is $20.9 \%$. The elevation ranges between $2 \mathrm{~m}$ a.s.l. in the coastal parts and $2121 \mathrm{~m}$ a.s.1. in the mountainous areas. 
Table 1- Morphometric parameters

\begin{tabular}{|l|c|c|c|c|}
\hline \multicolumn{1}{|c|}{ Drainage Basin } & $\begin{array}{c}\text { Area } \\
\left(\mathbf{k m}^{\mathbf{2}}\right)\end{array}$ & $\begin{array}{c}\text { Mean slope } \\
\mathbf{( \% )}\end{array}$ & $\begin{array}{c}\text { Range of } \\
\text { elevation (m) }\end{array}$ & $\begin{array}{c}\text { Mean } \\
\text { elevation (m) }\end{array}$ \\
\hline Aposelemis basin & 122.7 & 15.5 & $0-1541$ & 441 \\
\hline Lasithi-Katharo plateau & 129.2 & 12.7 & $884-2121$ & 1125 \\
\hline Rest of Dikti mountain & 451.5 & 20.9 & $2-2121$ & 878 \\
\hline
\end{tabular}

\section{Geological and Hydrogeological settings}

\subsection{Geology}

There are many scientific publications related to the geology of the study area (Seidel 1978, Fytrolakis 1980, Alexopoulos 1990, 1993-94, 2001, Bouloukakis 1999). The study area is characterized by the presence of successive thrust sheets (tectonic zones). The pre-neogene basement consists of the Plattenkalk series (or Kriti-Mani unit), the Phyllite-Quartzite series and the formations of Tripolis and Pindos zone. Younger rocks are: the Neogene deposits and the Quaternary clastic sediments (Fig. 2). The aforementioned zones are described below:

\section{Plattenkalk series (or Kriti-Mani unit)}

The lithostratigraphic column of the Plattenkalk series comprise, from the bottom to top: a) medium-bedded and, more rarely, thick-bedded, usually greyish, blackish and light-gray marbles, including scare chert intercalations and light-gray chert nodules whose length reaches up to $20 \mathrm{~cm}$. Locally, the calcareous rocks appear dolomitised. b) Yellowish or grey-green phyllites and calcphyllites incorporating rare, thin white quartzite intercalations. c) Thin-bedded or medium-bedded, crystalic limestones with rare chert nodules at the lower parts and frequent intercalations of thinbedded light gray or black cherts at the middle and upper parts. At the upper parts, microbreccia or coloured (green or red-violet) marble horizons occur. d) Green and red-violet calc-phyllites, with gradual increase in argillic material, characteristic of the transitory-to-the-metaflysch layers. The main tectonic features characterizing the Plattenkalk series are: 1) the faults having large throw and length, 2) the large-scale overfold folds and 3) the imbricated structure. The tectonic fabric is completed by meso- and microscopic folds, cleavage, lineations, minor faults and joints. The Plattenkalk series have been metamorphosed in high pressure-low temperature conditions. These series is considered to be the relative autochthonous zone.

\section{Phyllite-Quarzite series}

The tectonic nappe of the Phyllite-Quartzite series consists of a) a variety of greenish schists, mainly chloritic-sericitic ones, black, more or less graphitic schists, that usually intercalate with thin grey quartzitic layers, b) quartzite - schist alterations c) schist - thin bedded marble alterations and d) blonde-yellowish to red-yellowish schists containing spare quartzitic layers. The Phyllite-Quartzite series have undergone HP/LT metamorphism and are characterized by the presence of Variskian metamorphic rock. It is thrusted on the autochthonous zone of Plattenkalk. This unit acts hydrogeologically as the impermeable substrate (Alexopoulos 1990, 1993-94).

\section{Tripolis zone}

Three lithostratigraphic sub-units represent the Tripolis zone in the stady area: i) the Ravdouha or Tyros beds, ii) the carbonate series and iii) the flysch. The Ravdouha beds constitute the volcanosedimentary basement of the Tripolis carbonate series. They are characterized by the present redviolet or green phyllites with thick or thin quartzitic layers, coarse-grain thick bedded limestones, stromatolitic dolomites and porphyritic andesites. The carbonate series consists from thick-bedded dolomite, micritic or laminated dolomites or dolomitic limestones, stromatolitic limestones, dolomitic as well as limestones breccias and finally, thick to medium bedded limestones of 
different types and different colour (from black to white). The thickness of carbonate series is estimated to exceed $3,000 \mathrm{~m}$. The carbonate series is intense tectonised. Faults and joint systems favour karstification and infiltration. The flysch comprises marls, pelites, sandstones, conglomerates, brecciated limestones and volcanic bodies (Krahl et al. 1983, Alexopoulos 1990).

\section{Pindos zone}

The Pindos zone represents the highest nappe in the study area. It consists of middle Triassic to upper Eocene, thin to medium bedded limestones and intercalations of thin-bedded limestones, white-gray or red cherts, yellow argillic shales and red pelites. The base of the sequence consists of "first flysch" formation which comprises sandstones, pelites and limestones, while at the top we have the present of the normal flysch. Faults, joints, folds, imbricated thrusts and stylolites compose the tectonic fabric of the Pindos zone (Alexopoulos 1990).

\section{Postalpine sediments}

The postalpine sediments consist of a) monomixed or polymixed conglomerate, as well as bedded or non bedded yellowish clays, marls, sandstones and marly or bioclastic limestones, of Upper Miocene age, which cover unconformably the carbonate sequences and b) Plio-Quaternary clastic sediments. The latter consist of sandy-clayey materials, beach sands, conglomerates, sandstones and breccias.

The tectonic setting in the area is controls the flow of the karst ground water. In the study area folding and fracture tectonics are both present. Three groups of normal faults are mostly abundant: W-E, NNE-SSW and NE-SW, affecting the direction of groundwater movement (Alexopoulos 1990, 1993-94).

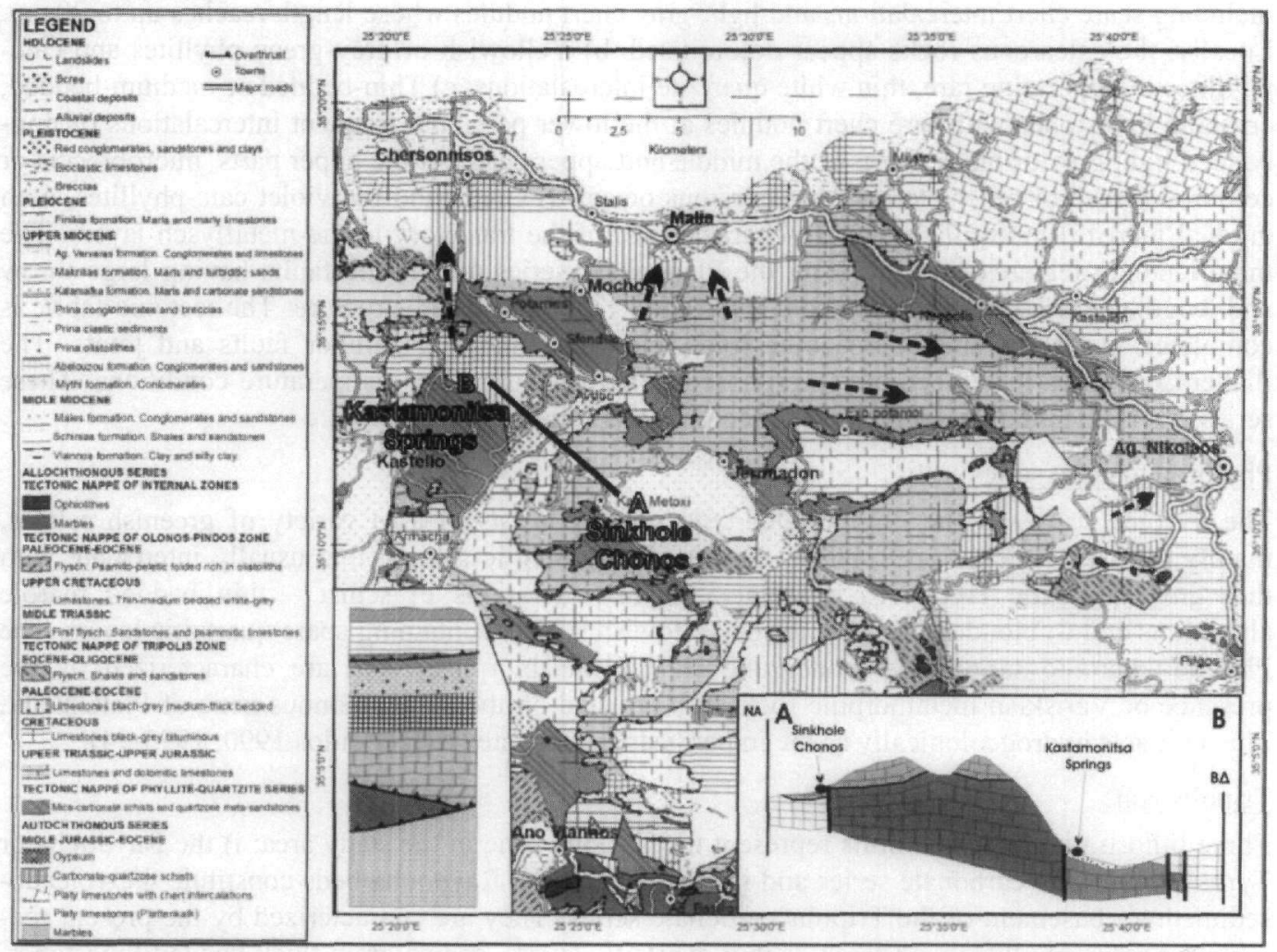

Figure 2-Geological map of the study area 


\subsection{Hydrogeology}

\subsubsection{Hydrogeological behaviour of the geological formations}

The lithologically heterogeneous carbonate series has variable permeability. However, the limestone members of the sequence are well karstified. The series host several aquifers with different base-levels that are in hydraulic inter-communication. In many cases fractures with wide openings install direct hydraulic communication between karst systems and seawater. The most promising aquifers are hosted in the Plattenkalk, in the carbonates of Tripolis zone and the marly limestones of Neogene. The hydrogeological behaviour of these formations is controlled by tectonic deformation, which favours infiltration. The depth of the aquifers varies according to the depth of the "base level", usually impermeable substrate or the sea level in coastal zones. The presence of the impermeable Phyllite-Quartzite series controls substantially the hydrogeological regime of the area, since these rocks are intercalated between carbonate rocks, thus modifying groundwater flow.

Deep boreholes in the Plattenkalk series at the western piedmonts of Dikti mountain revealed active karstification in elevations ranging from 60 to $150 \mathrm{~m}$ below the mean sea level. The "Plattenkalk" aquifers are recharged from direct rainfall infiltration, runoff from Aposelemis and from Lasithi plateau.. The infiltration coefficient is high of the order of $50 \%$. The mean specific capacity of water boreholes in the "Plattenkalk", dependent on the grade of their deformation and jointing and on the grade of fill of fissures with "terra rossa", is $68 \mathrm{~m}^{3} / \mathrm{h} . \mathrm{m}$ (Bouloukakis and Voudouris 1997). Transmissivity values vary between 285 and $950 \mathrm{~m}^{2} / \mathrm{d}$, as deduced from pumping test analysis. The elevation of static water table ranges from +15 to $+100 \mathrm{~m}$. a. m.s.l. The seasonal fluctuation of ground water table in these aquifer systems ranges from 15 to more than 35 $\mathrm{m}$, due to their high transmissivity and low storativity (Koumantakis et al. 2005).

The carbonate rocks of Tripolis zone are very tectonised and karstified and show a high permeability. They host a very anisotropic karst aquifer with significant productivity. They have high transmissivities and medium storativities. Nevertheless, due to their significant volume of stored water they are a prominent aquifer. Based on Maillet equation, the mean value of the recession coefficient (a) for karst springs draining karst aquifers of Tripolis zone is $9.10^{-3} \mathrm{~d}^{-1}$, indicating high rate of aquifer evacuation (Voudouris 2003). The Phyllite-Quartzite series forms the impervious basic layer of carbonates rocks of Tripolis zone. Therefore contact karst springs occur at their boundaries with the overlying carbonates. In places the carbonate unit of the Tripolis zone is in direct contact with the Plattenkalk, due to the absence of Phyllite-Quartzite series. The discontinuities of the karst aquifer, locally, are filled with "terra rossa" reducing their permeability. The transmissivity of karst aquifer of Tripolis carbonates varies between 24 and $1460 \mathrm{~m}^{2} / \mathrm{d}$. The specific capacity of boreholes ranges from $1-51 \mathrm{~m}^{3} / \mathrm{h} . \mathrm{m}$. The aquifer is in direct hydraulic communication with seawater in the northern part of the study area (Gouves region). The water is of calcium-bicarbonate type (fresh water) in the inland part of the karst aquifer and of $\mathrm{Na}-\mathrm{Ca}-\mathrm{Cl}-$ $\mathrm{HCO}_{3}$ or $\mathrm{Na}-\mathrm{Ca}-\mathrm{Cl}$ type (brackish water) in the coastal part of the aquifer, due to seawater intrusion. The front of sea water intrusion continues to move further towards the inland.

The Pindos carbonates have low karstification and medium secondary porosity. They are least important for the water economy of the area. Their low water capacity is the result of the occurrence of aquiclude formations (flysch) in the Pindos carbonate zone, of the small thickness of limestones and of restricted outcrops. Where the flysch is tectonically lacking, hydraulic connections can occur between the Pindos and the Tripolis aquifer system. Water that infiltrates from rainfall recharges the deeper karst aquifer of Tripolis zone.

In the northern part of the study area (Chersonisos) outcrop the marly or bioclastic limestones of the Neogene formations, which have a high permeability, associated with karstification and secondary porosity. Therefore they host a significant karst aquifer. The latter communicate 
hydraulically with the underlying karst aquifer of Tripolis zone. Pumping test results indicate that transmissivity values of the aquifer range between 104 and $2300 \mathrm{~m}^{2} / \mathrm{d}$ and that mean storativity is of the order of 0.025 .

\subsubsection{The karst aquifer system of the rest of the Dikti mountain drainage area}

Due to the nature of the several aquifer systems in the carbonates of the Dikti mountain and their inter-dependence intercommunication and interrelation it is not wise to study the Aposelemis and Lasithi hydrological and hydrogeological behaviour and conditions without considering the ones of the rest of the Dikti mountain. The karst aquifer in carbonate rocks of the rest of Dikti mountain drainage basins has high permeability, due to its intense fracturing and karstification. The percentage of annual precipitation infiltrating into the carbonates is estimated to be around $50 \%$. The karst system of the rest area of Dikti mountain consists of semi-independent intercommunicating hydrogeological units. Groundwater flow is controlled by the pattern of the existing fracture system. The hydrogeological units are drained by springs. During the last decades, this aquifer is exploited by deep boreholes. In the northern part of the region the karst aquifer system is drained by submarine springs in the Cretan sea. The karst system of the rest of Dikti mountain is medium to high permeable, with moderate salt water intrusion and coastal submarine springs (Perleros 2004).

\subsection{Hydrometeorological conditions}

The island of Crete has a Mediterranean climate, with wet winters and hot, dry summers. The hydrological year is considered to last from October to the end of September of the next year. Over about $85 \%$ of the annual rainfall occurs during the wet period from November to April. The mean annual temperature is $18{ }^{\circ} \mathrm{C}$ in the coastal areas; February is the coldest month and July is the hottest one. Maximum temperatures of $35{ }^{\circ} \mathrm{C}$ are common in summertime. The relationship between temperature $(\mathrm{T})$ and topographic elevation $(\mathrm{h})$ is: $\mathrm{T}\left({ }^{\circ} \mathrm{C}\right)=-0.0083 \mathrm{~h}(\mathrm{~m})+18.22\left(\mathrm{R}^{2}=0.87\right)$. Potential evapotranspiration exceeds rainfall from April to October, implying that most groundwater recharge occurs from November to April (Voudouris et al, 2006a).

\subsubsection{Rainfall}

During the present study, monthly rainfall data were collected from 7 stations at the wider area for the period 1967-2003. Rainfall during missing monthly observations, which were randomly distributed throughout the operational period of only few stations, was estimated using the normal-ratio method. The control of the homogeneity of rainfall data is based on the method of double mass curve and the criterion of Bartlett. The results obtained showed that all the selected stations are homogeneous (Mavrommatis and Voudouris 2006). The average annual precipitation (P) at each station was calculated from the monthly data and plotted against the altitude (h) of that station (Fig. 3a). A regression line fitted to these data (see Fig. 3a) indicates the following relationship between the rainfall $(\mathrm{P})$ and the altitude $(\mathrm{h}): \mathrm{P}=0.65 \mathrm{~h}+543.7\left(\mathrm{R}^{2}=0.89\right)$

The above relationship was spatially implemented in Figure 4 with the use of the raster calculator of ArcView GIS and DEM, in order to calculate the long term mean annual rainfall in Aposelemis basin, Lasithi plateau and Dikti area. The map shows that the rainfall in the central mountainous part is high and decreases towards the northern and southern parts of the study area. A recent study, found that annual rainfalls show a decreasing linear trend (Voudouris and Kallergis 2002).

\subsubsection{Evapotranspiration}

In order to assess the evapotranspitation the Thornthwaite-Mather method (Thornthwaite and Mather 1957) was applied, using GIS technology. Based on this approach, the coefficient of the actual evapotranspiration at the Heraklion, Avdou, Kastelli and Jermiado stations, in which there were available data of temperature and rainfall, was estimated to range between $62 \%$ and $78 \%$ of the annual precipitations in lowlands and between 38 and $50.5 \%$ in the mountainous area. The relationship is expressed by the regression line (Fig. $3 b)$ : $E_{r}=-0.032 h+77.2\left(R^{2}=0.91\right)$, where $E_{r}$ is 

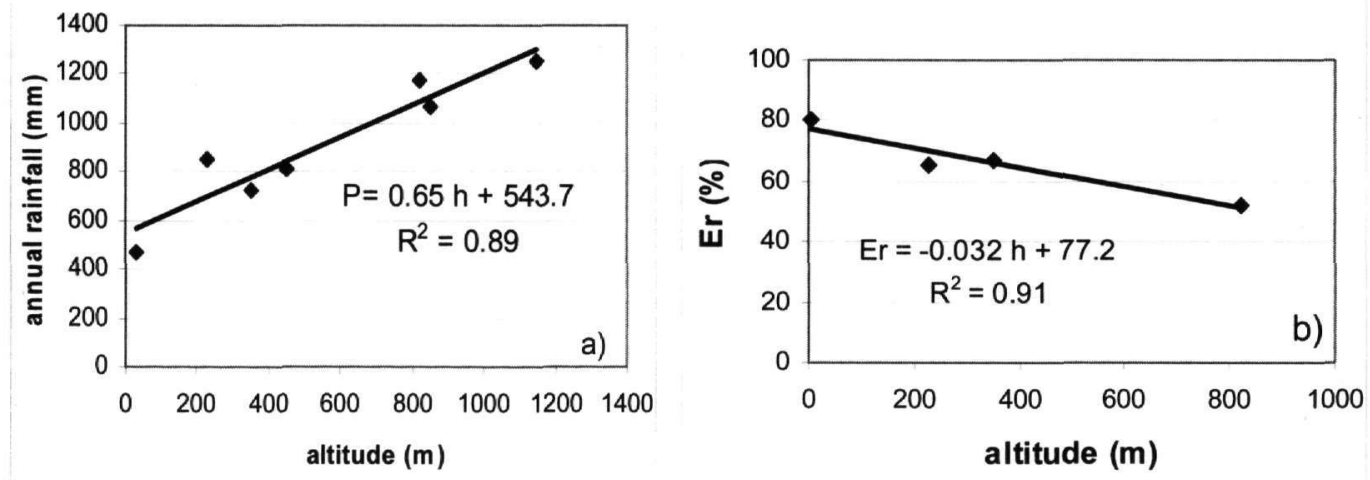

Figure 3 - a) Relation between average annual rainfall $(\mathrm{mm})$ and altitude $(\mathrm{m})$ (left) and b) coefficient of actual evapotranspiration (\%) vs altitude (right)

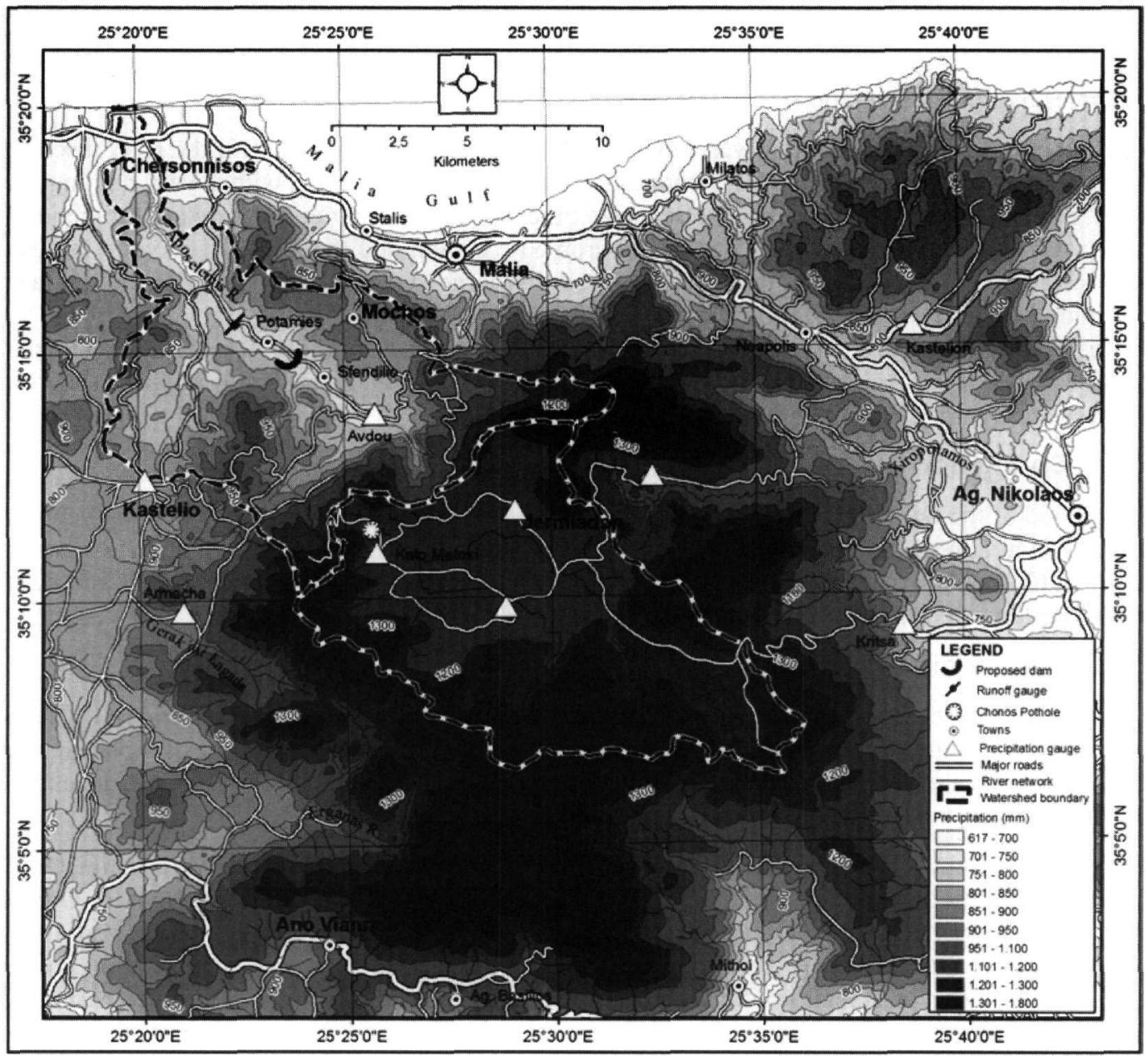

Figure 4 - Distribution of annual rainfall (mm) 
the actual evapotranspiration $(\%)$ and $\mathrm{h}$ is the altitude $(\mathrm{m})$. The maximum water storage in the soil was estimated to be $110 \mathrm{~mm}$ for post-alpine deposits and $60 \mathrm{~mm}$ for limestones (Voudouris 2006).

\subsubsection{Streamflow}

Streamflow in the Aposelemis river and the torrents of the study area persists throughout the wet period. The sites of the stream flow gauge stations are at Potamies and Chonos sinkhole (Fig. 4). The discharge records of the hydrographs in the Aposelemis river at the Potamies hydrometric station and at the "Chonos" sinkhole for the period 1962/1963 through the 2000/2001 hydrological years (20 hydrological years, Ministry of Agriculture) were processed (Figs 5, 6).

The mean annual discharge of Aposelemis at Potamies station is $10.7 \times 10^{6} \mathrm{~m}^{3}$ (surface of the drainage area $76 \mathrm{~km}^{2}$ ), whereas the mean annual discharge at Chonos sinkhole is $16.6 \times 10^{6} \mathrm{~m}^{3}$. The measurements at Chonos represent water that is leaving the Lasithi plateau and flows into the sinkhole. An amount of this volume is discharged through springs Ag. Georgios (Kastamonitsa) and then contributes to Aposelemis streamflow and recharges significantly the downstream karst aquifer systems of Tripolis zone. Another amount recharges the karst aquifers all around the Dikti Mountain. Based on hydrologic balance, Voudouris (2006) suggests that an average amount of $4.3 \times 10^{6} \mathrm{~m}^{3} / \mathrm{yr}$ from Lasithi plateau recharges the Aposelemis basin through Chonos sinkhole and then through springs of Ag. Georgios. From this is depicted the important role of Aposelemis streamflow and of Chonos drainage to the recharge of the karst aquifer systems, downstream of the Potamies hydrometric station.

The time lag between the rainfall variations and the corresponding response in the river discharges was investigated by performing cross-correlation analysis on the filtered, with 1-year running mean filter, normalized monthly anomalies of the two time series. By using cross-correlation function between Aposelemis streamflow at Potamies hydrometric station and the rainfall at Avdou raingauge station (Fig. 7), it is concluded that, the measured discharges were found to precede the rainfall by one month, due to the contribution to the streamflow from Lasithi plateau through springs (Voudouris et al. 2006b; Mavrommatis and Voudouris 2006). Long-lasting dry periods result in significant decrease of the Aposelemis streamflow that recharges the karst aquifers in Malia-ChersonisosGouves area (Kallergis et al. 2000).

\subsubsection{Spring flow}

All around of the Dikti mountain many karst springs are inventoried at elevations ranging between 2 and $750 \mathrm{~m}$ a.m.s.l. Some of them are brackish (e.g. Almyros Ag. Nikolaos, Elounda, Emparos, Grammatikaki, Almyros Malion) with chloride concentrations ranging between 1200 and 3300 $\mathrm{mg} / \mathrm{L}$ (Perleros 2004). The mean annual discharge of Almyros Ag. Nikolaos spring is $70 \times 10^{6} \mathrm{~m}^{3}$.

\subsubsection{Hydrologic balance}

Hydrologic balance components were estimated, using the Thornthwaite method and GIS technique. Table 2 shows an estimated hydrologic balance for Aposelemis basin, Lasithi plateau and the drainage area of the Dikti. The surface area of Aposelemis drainage basin taken into account is that upstream of the hydrometric station at Potamies.

From the Thornthwaite-Mather method the coefficient of actual evapotranspiration is estimated to be $38.4 \%-58 \%$ of the annual rainfall. Infiltration coefficients of similar formations in Greece were adopted for the geological formations of the study area (Voudouris 2006). The spatial distribution of the infiltration coefficients derived from the product of the raster of infiltration coefficients to the raster of annual rainfall amounts. The analysis was accomplished on the basis of a raster grid with a cell size of $50 \mathrm{~m} \times 50 \mathrm{~m}$.

Based on results of tracing analysis (Kylili- Polichronaki, \& Vitoriou, IGME 2006), is concluded that there is hydraulic communication between the Chonos sinkhole and the karst aquifers all 


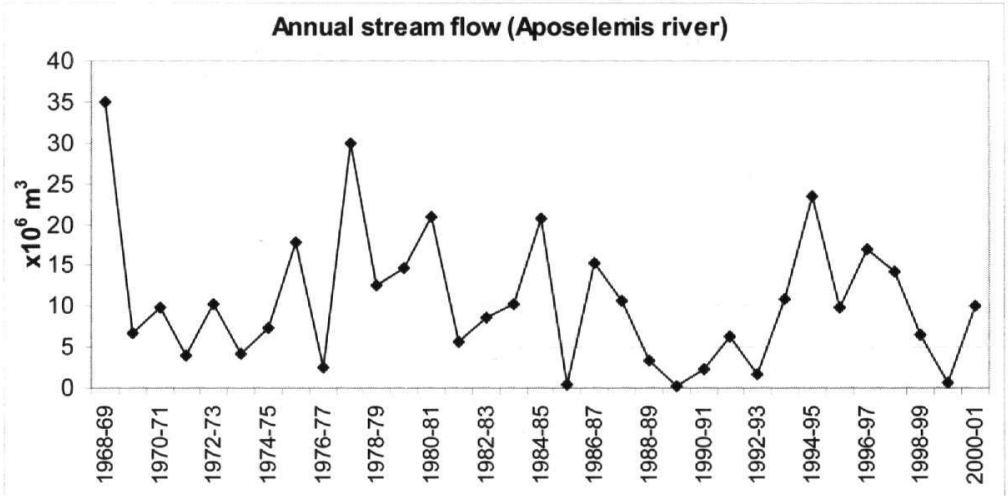

Figure 5 - Hydrograph of annual discharge in Aposelemis basin

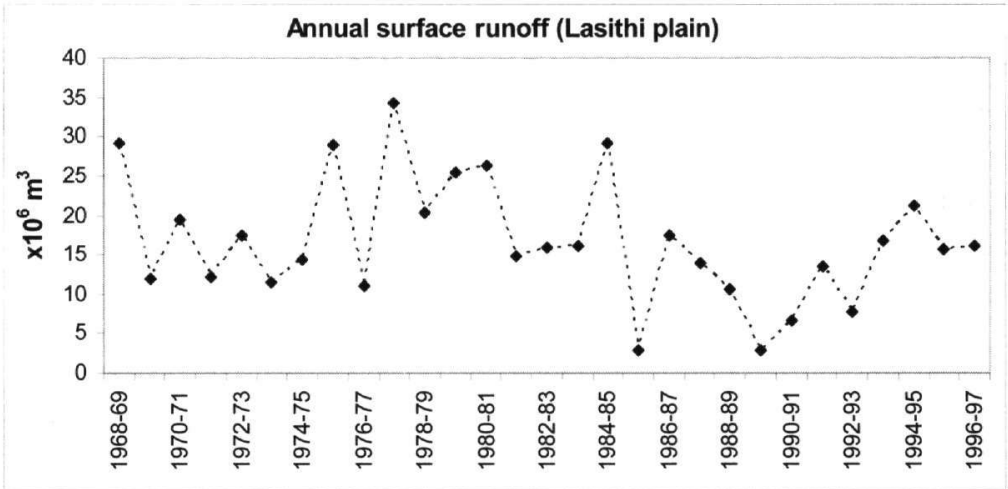

Figure 6 - Hydrograph of annual discharge in Lasithi plateau

APOSELEMIS - ABDOU

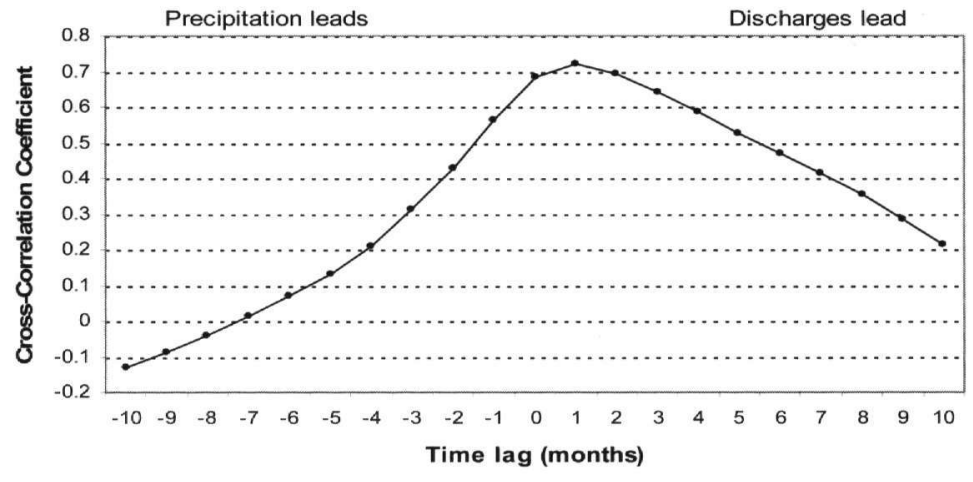

Figure 7- Cross correlation coefficient between rainfall (Avdou station) and discharge of Aposelemis at Potamies station during the period 1967/68-2000/01 (Voudouris et al. 2006b) 
Table 2 - Hydrological balance

\begin{tabular}{|c|c|c|c|c|}
\hline Drainage Area & 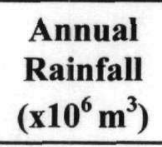 & $\begin{array}{c}\text { Evapotranspiration } \\
\qquad\left(\mathrm{x}^{6} \mathrm{0}^{6} \mathrm{~m}^{3}\right)\end{array}$ & 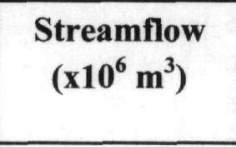 & $\begin{array}{c}\text { Infiltration } \\
\left(\mathbf{x 1 0}^{6} \mathrm{~m}^{3}\right)\end{array}$ \\
\hline Aposelemis basin* & 70.5 & $40.9(58 \%)$ & $10.7(15.2 \%)$ & $18.9(26.8)$ \\
\hline Lasithi plateau** & 161.9 & $71.8(44.3 \%)$ & $16.6^{* *}(10.3 \%)$ & $73.5(45.4 \%)$ \\
\hline $\begin{array}{l}\text { Rest drainage area } \\
\text { of Dikti mountain }\end{array}$ & 470.0 & $180.3(38.4 \%)$ & $29.1(6.2 \%)$ & $\begin{array}{c}260.6 \\
(55.4 \%)\end{array}$ \\
\hline
\end{tabular}

* Upstream of hydrometric station at Potamies

**Based on measurements at Chonos sinkhole

around the Dikti and neogene aquifers of Thrapsano plain as well. The velocity of water was estimated to be $108-376 \mathrm{~m} / \mathrm{d}$. Tracer was injected in the Chonos sinkhole of the Lasithi plateau.

\section{Conclusions}

- The geologic setting of the wider area of Dikti mountain is formed by successive nappes of the Kriti-Mani ("Plattenkalk") series, the Phyllite-Quartzite series and of the Tripolis and Pindos zones. The stratigraphic sequence terminates with Neogene deposits consisting of bioclastic, or marly limestones and Quaternary clastic sediments.

- The hydrogeological behaviour of these series is controlled by tectonic deformation, which favours infiltration and karstification. The main aquifers are developed in the Plattenkalk, in the carbonates of Tripolis zone and in the marly limestones of Neogene. Locally, the karst aquifers are directly hydraulically connected with sea. Karst aquifer systems are drained by a great number of springs, namely coastal, submarine and inland, discharging brackish or fresh water.

- Hydrologic balance components were estimated, using the Thornthwaite method and GIS technique. The calculated mean annual precipitation in Dikti mountain is $1041 \mathrm{~mm}$, corresponding to $470 \times 10^{6} \mathrm{~m}^{3} / \mathrm{yr}$. Out of this amount, a volume of water of $260.6 \times 10^{6} \mathrm{~m}^{3} / \mathrm{yr}$ infiltrates in the carbonate rocks recharging the karst aquifers. From the ThornthwaiteMather method the coefficient of actual evapotranspiration is estimated to be $38.4 \%-58 \%$ of the annual rainfall.

- The mean annual discharge of Aposelemis at Potamies station is $10.7 \times 10^{6} \mathrm{~m}^{3}$, whereas the mean annual discharge at Chonos sinkhole is $16.6 \times 10^{6} \mathrm{~m}^{3}$. The Aposelemis streamflow recharges significantly the downstream karst aquifer systems.

- Tracer studies carried out by IGME confirmed that there is hydraulic communication between the Chonos sinkhole of Lasithi plateau and the karst aquifers all around the Dikti mountain and neogene aquifers of Thrapsano plain as well. The direct connection between Aposelemis and Lasithi was also confirmed from the hydrological balance of Aposelemis drainage basin.

Rational water resources management, based on conjunctive use of surface and groundwater, should be applied in the study area aiming at sustainability of the karst aquifer systems, which are particularly vulnerable. The knowledge of hydrologic parameters is a useful tool for the rational water resources management. Future investigations of the hydrological balance would benefit by improvement in hydrological data monitoring, the application of isotopic analysis and computer modelling to simulate the water cycle. 


\section{References}

Alexopoulos, A., 1990. Geological and hydrogeological investigations in the region of Mochos, Crete, $P h D$ thesis, University of Athens (in Greek).

Alexopoulos, A., 1993-94. The impact of the geological structure of the western piemonts of Lassithiotika mountains on the hydrogeological conditions of the area and the development of karstic forms and caves, Bulletin de la Société Spéléologique de Grèce, XXI, 62-71.

Alexopoulos, A., 2001. On the Geological and Hydrogeological conditions between Malia, Mohos, Potamia and Limenas Hersonissou, Crete, Proc. $9^{\text {th }}$ International Society of Greece, XXXIV, 5, 1783-1791.

Bouloukakis, H., and Voudouris, K., 1997. Pumping test evaluation in Plattenkalk of Crete, Proc. $4^{\text {th }}$ Hydrogeol. Conference, Thessaloniki, 324-336pp.

Bouloukakis, H., 1999. Hydrogeological and geophysical investigation of NE part of Heraklion Prefecture, PhD thesis, Dept. of Geology, University of Patras.

Chartzoulakis, K.S., Paranychianakis, V., and Angelakis, A.N., 2001. Water resources management in the island of Crete, with emphasis on the agricultural use, Water Policy, 3, 193205.

Fytrolakis, N., 1980. Geological structure of Crete island. National Technical University of Athens. Institute of Geology and Mineral Exploration (IGME) (1989) Geological map of Greece 1:50000. Mochos sheet, Athens.

Krahl, J., Kaufmann, G., Kozur, H., Richter, D., Forster, O., and Heinritzi, F., 1983. Neue Daten zur Biostratigrafie und zur tektonischen Lagerung der Phyllit-Gruppe und der TrypaliGruppe auf der Insel Kreta (Griechenland), Geol. Rundsch., 72, 1147-1166.

Kallergis, G., Lambrakis, N., and Voudouris, K., 2000. Hydrogeological investigation of Chersonisos area. Technical report. Lab. of Hydrogeology, University of Patras. (unpublished)

Koumantakis, J., Markantonis, K., and Foti, S., 2005. Contribution at Hydrogeology of adjacents karstic systems of malia and Hersonisos, Crete, Proc. $7^{\text {th }}$ Conference on Hydrogeology, Athens, 203-210. (in Greek)

Kylili-Polichronaki, A., and Vitoriou, A., 2006. Results of the experiment of tracing in the sinkhole Chonos of Lasithi plateau. IGME. Technical report. (unpublished)

Lambrakis, N., 1998. The impact of human activities in the Malia coastal area (Crete) on groundwater quality, Environmental Geology, 36 (1-2) November 1998, 87-92.

Mavrommatis, Th., and Voudouris, K., 2006. Relationship between the hydrological parameters using correlation and trend analysis in Crete island, Greece, Env. Hydrology. (in press)

Perleros, B., 2004. The main coastal karstic aquifers of southern Europe. COST Action 621, EUR 20911, 77-79.

Seidel, E., 1978. Zur Petrologie der Phyllit-Quartzit Serie Kretas, PhD dissert, Techn. University Braunschweig, 145pp.

Thornthwaite, CW., and Mather, J.R., 1957. Instructions and tables for computing potential evapotranspiration and the water balance, Vol. 10, No 3, CW Thornthwaite Associates, Laboratory of Climatology, Elmer, New Jersey, USA.

Voudouris, K., and Kallergis, G., 2002. Changes of the rainfall regime in South Greece and water resources management, Proc. $6^{\text {th }}$ Conference on Hydrogeology, Xanthi, 107-118. (in Greek) 
Voudouris, K., 2003. Hydrogeological characteristics of the karst aquifers in central Crete, Greece, Proc. of XXX IAHR Congress "Water Engineering and Research in a Learning Society", 24-29 August, Thessaloniki, vol. B, 903-910.

Voudouris, K., Mandilaras, D., and Antonakos, A., 2004. Methods to define the seawater intrusion: examples from South Greece, Groundwater and saline intrusion, Selected papers from the $18^{\text {th }}$ Salt Water Intrusion Meeting, Cartagena, Spain, 465-480.

Voudouris, K., Mavrommatis, Th., Daskalaki, P., and Soulios, G., 2006a. Rainfall variations in Crete island (Greece) and their impacts on water resources, Publicaciones del Instituto Geologico y Minero de España. Serie: Hidrogeologia y aguas subterráneas No 18, Karst, Climate change and Groundwater, 453-463, Madrid.

Voudouris, K., Mavrommatis, Th., Antonakos, A., and Vouvalidis, K., 2006b. Study of river discharge-rainfall relation in the basin of Aposelemis, Abstracts $8^{\text {th }}$ Conf. MeteorologyClimatology (poster presentation).

Voudouris, K., 2006. Estimation of the hydrological balance in the wider area of Aposelemis basin, Crete. Technical report. Lab. of Engineering Geology \& Hydrogeology, Dept. of Geology, Aristotle University of Thessaloniki. (unpublished) 